\title{
Nosocomial infections in neonatal intensive care unit In Pediatric Assiut University Hospital: incidence and risk
}

\section{factors}

\author{
Asmaa Mohamed Ahmed Soliman*, Eman Morsy Mohamed*, Kawthar Abd El-Motagaly \\ Fadel $^{\star}$, Samia Atwa Mohamed ${ }^{\star *}$, Enas Mohamed Abd El-Megeed Daef ${ }^{\star * *}$.
}

\begin{abstract}
Background: Nosocomial infections (NIs) have become a matter of major concern in neonatal intensive care units (NICUs). Nosocomial infections are the result of the interaction of several risk factors. Objective: to identify risk factors for nosocomial infections among neonates admitted to neonatal intensive care unit in Pediatric Assiut University Hospital (AUH). Knowledge of modifiable risk factors could be used to guide the design of interventions to prevent the problem. Methods: Incidence (surveillance) study for identification of new nosocomial infections for one year \& 9 days from (17 of April 2007 to 26 of April 2008). The total population: All neonates attending $\mathrm{NICU}$ in pediatric AUH from the Obstetric Department of Maternal-Healthcare Assiut University Hospital. The target population is all neonates that developed nosocomial infections within $72 \mathrm{hrs}$ of admission. The presence of risk factors was studied. A practical guide completed for each patient, which included: Demographic risk factors as age, birth weight, sex, single or multiple births, type of delivery, premature rupture of membranes, variables recorded daily as enteral feeding, parenteral feeding, mechanical ventilation and indwelling catheter. Differences between patients with and without $\mathrm{NI}$ for discrete variables were estimated by the chi-square test. The association between risk factors and the presence of NIs were estimated by relative risk. Results: from a total of 990 admitted neonates, the incidence rate and the incidence density rate were $16 \%$ and $24.45 \%$ infections per 1000 patient-days, respectively. Case fatality rate was $91.8 \%$. The following risk factors were associated with NIs $(P<0.05)$ : mechanical ventilation, umbilical catheter, prematurity, birth weight less than $1500 \mathrm{~g}$, use of ryle, transport outside NICU, premature rupture of membrane \& peripheral vascular catheter. Conclusion: The risk of Nls increases with increasing invasive devices, decreasing birth weight, and gestational age. There is an increased mortality rate associated with NI. Strategies to minimize the impact of risk factors must be identified.
\end{abstract}

\section{INTRODUCTION}

Nosocomial infection in the neonatal intensive care unit (NICUs) is the result of the interaction of several risk factors. immune system immaturity, exposure to broad-spectrum antibiotics, and the high likelihood of cross-infections due to close contact with a multidisciplinary team have all been related to the occurrence of

\footnotetext{
*Public Health \& Community Medicine Department, Faculty of Medicine,

${ }^{* *}$ Neonatal Intensive Care Unit in Pediatric Assiut University Hospital,

${ }^{* * *}$ Infection Control Laboratory.
} 
nosocomial infections. Prolonged duration of NICU stay (probably a surrogate marker of the patient's severity of illness), and low birth weight have also been related to an increased risk of nosocomial infections. Intensive use of invasive medical devices (i.e., urinary catheters, central venous catheters [CVCs], and mechanical ventilators) for both diagnostic and therapeutic purposes probably account for the greater risk of nosocomial infections ${ }^{(1)}$.

Nosocomial infection (NI) is a major cause of morbidity and mortality in neonatal intensive care nurseries ${ }^{(2,3)}$ and affects the cost of medical care by increasing resource consumption and the duration of hospitalization in developed countries $^{(4)}$.

Major risk factors for $\mathrm{NI}$ include: low birth weight and gestational age, respiratory disease, mechanical ventilation, use of central catheters, use of nasogastric tubes, and parenteral nutrition(2,3,5) thus, available data suggest that medical interventions are important risk factors for $\mathrm{NI}$ in neonates. The extent to which these findings apply to developing countries, in which financial resources for heath care are limited, is unclear(6).

Advanced medical technology such as the closed system of a central line and tracheal tube in the neonatal intensive care unit (NICU) has improved the quality and length of life of neonates born with prematurity and congenital defects. However, nosocomial infection risks are high in NICU babies due to their immature immune systems and the need for invasive diagnosis and treatment, causing high mortality and increases in medical $\operatorname{costs}^{(4,7,8,9)}$.

The incidence of nosocomial infection ranges from $6 \%$ to $25 \%$, with a large amount of variation by birth weight and treatment condition ${ }^{(2,10)}$. Nosocomial infections could be prevented by instituting careful bacteriologic surveillance, improving hand hygiene, and limiting 
antibiotics and invasive procedures ${ }^{(11-16)}$. Therefore, it is very important to determine the incidence of nosocomial infection, to identify risk factors for $\mathrm{NI}$ that give Knowledge of modifiable risk factors for $\mathrm{NI}$ which would enable developing countries to implement interventions to decrease $\mathrm{NI}$ and associated complications.

In view of the limited literature and studies on NIs in pediatric ICU or neonatal ICU, in developing countries, this study was conducted in neonatal intensive care unit in Assiut Pediatric University Hospital (the first study), in order to know the size of the problem (NIs) among neonates and to identify risk factors for nosocomial infections among infants.

\section{MATERIAL and METHODS:}

Incidence study (the first study) prospective identification of new nosocomial infections (incidence surveillance) for one year \& 9 days from (17 of April 2007 to 26 of April 2008).

The total population: All neonates attending NICU in Pediatric AUH from the

Obstetric Department of Maternal Healthcare Hospital.

The target population is all neonates that developed nosocomial infections within 72 hrs of admission according to the Centers for Diseases Control and Prevention (CDC)/National Nosocomial Infection Surveillance (NNIS) definitions for NIs for infants $\leq 12$ months ${ }^{(17)}$.

- Inclusion criteria: All neonates admitted to NICU who born in the obstetric department of Maternal Healthcare Hospital.

- Exclusion criteria: if neonates developed infections before or within 48 hrs of admission were generally considered maternally acquired and neonates born outside AUH.

Practical guide was constructed to be the tool of data collection. Using a practical guide, one form was completed for each neonate. 
The guide included two parts:

The first part was used for all admitted inborn neonates in NICU and included:

Demographic risk factors:

- Age (gestational age): $<37$ ws = preterm.

- Birth weight category : $<1000$ $\mathrm{g}, 1000-, \geq 1500 \quad(<1500 \mathrm{~g}=$ premature).

- $\quad$ Single or multiple births.

- Type of delivery (caesarian section or vaginal).

- Premature rupture of membranes (>24 hs before delivery).

- Presence of meconium stained amniotic fluid.

Time dependant variables were recorded daily:

- Presence or absence of enteral feeding

- Presence or absence of parentral feeding with pre-prepared (TPN $\rightarrow$ Amino-venous) or prepared in the Neonatal Intensive Care Unit.
- Mechanical ventilation

- Indwelling catheter (peripheral vascular catheter \& umbilical catheter).

- Transport out side the NICU.

- Outcome.

The second part of the practical guide was used for neonates who developed nosocomial infections and included:

- Date of onset of infection.

- Microorganisms isolated and antimicrobial susceptibility.

Data were obtained from hospital records, nursing notes and oral communication with the attending physicians.

- Blood samples were taken from cases of $\mathrm{NI}$ for blood cultures, and complete blood count.

Data revision, computer data entry \& statistical analysis:

All data were revised, coded, and were subjected to computer entry and analysis to fulfill the objectives. The advanced 
Statistical Package for Social Sciences (SPSS) version 11 were used for statistical analysis. Description of the population (descriptive studies), frequency of risk exposure and infection rates were calculated as overall infection rate (per 100 admissions and 1000 patient-days). Denominators used to calculate the incidence of $\mathrm{NI}$ were daily number of admissions, and number of patient-days.

Differences between patients with and without NIs were estimated by the chisquare test. The association between risk factors and the presence of NIs were estimated by relative risk (RR) and their corresponding $95 \% \mathrm{Cl}$. The significance level used was $p$ less than 0.05 .

The birth weights of the babies were classified into 3 groups: $\geq 1,500 \mathrm{~g}, 1,000$ and less than $1,000 \mathrm{~g}$. The incidence of infections was determined in the birth weight groups.

\section{RESULTS}

Study population:
Total 990 neonates were admitted during the duration of surveillance from $17^{\text {th }}$ of April 2007 to $26^{\text {th }}$ of April 2008, total patient days were 6463 days.

Maximum weight for neonates was $5049 \mathrm{~g}$ and minimum weight was $527 \mathrm{~g}$ with the mean weight $1944 \pm 842 \mathrm{~g}$.

Table (1) shows the characteristics of study subjects. Males were $62.4 \%$ of total admitted while females were $37.6 \%$. $36.7 \%$ of neonates were less than $1500 \mathrm{~g}, 77.6 \%$ were premature (preterm), $71 \%$ of births were single and $53.7 \%$ of neonates were born by caesarean section. Premature rupture of membranes was present in $19 \%$ of cases.

Enteral feeding was used in $55.2 \%$ of neonates, of them $73.8 \%$ naso-gastric tubes were used. Mechanical ventilation was used in $52.6 \%$ of neonates, the use of peripheral vascular catheter was used in $63.1 \%$ of neonates and the use of central line (umbilical catheter) was used in $57 \%$ of cases. $24.9 \%$ of neonates were 
transported outside the NICU. $58.8 \%$ of admitted neonates were died (table 1).

Table (2) shows the incidence of nosocomial infection. One hundred and fifty eight (158) developed nosocomial infections within 72 hrs after admission. The cumulative incidence rate was 16 per 100 admitted neonates, incidence density was 24.45 neonates per 1000 patient days and the case fatality rate was $91.8 \%$.

The risk factors most closely associated with the development of NIs were mechanical ventilation (RR 4.4; 95\%, Cl 2.9-6.5), parentral feeding (amino venous) ( $\mathrm{RR} 4.2 ; 95 \%, \mathrm{Cl}$ 3.08-5.85), umbilical catheter (RR 2.5; 95\%, Cl 1.8$3.5)$, prematurity $(2.4 ; 95 \%, \mathrm{Cl} 1.5-3.9)$, weight less than $1500 \mathrm{~g}$ (RR 1.86; 95\%, Cl.0-2.08) and vaginal delivery (1.4; 95\%, Cl 1.04-1.85) use of naso-gastric tube
(Ryle) (RR 1.3, 95\%, $\mathrm{Cl}$ 0.99-1.8), Transport outside NICU (RR 1.3, 95\%, Cl 0.97-1.8), (table3).

The incidence of nosocomial infections was high in the weight group 1000-less than $1500(27.3 \%)$ \& was $16.4 \%$ in females. The incidence of infections by both gender \& birth weight was highest in both males \& females in weight group 1000-less than $1500(23.2 \%$ \& 33\%, respectively), (table 4).

The incidence of NIs was the highest in the preterm with $(+)$ mechanical ventilation. As regard incidence of NIs by birth weight \& mechanical ventilation, no difference in incidence between $<1500 \mathrm{~g} \mathrm{(+)} \mathrm{mechanical}$ ventilation $\&$ those $\geq 1500 \mathrm{~g} \mathrm{(}+)$ mechanical ventilation (25.4\% \& 24.9\%), respectively (table 5). 
Table (1): General results (characteristics) of admitted neonates at NICU in Pediatric Assiut University Hospital 2007-2008.

\begin{tabular}{|c|c|c|}
\hline Characteristics & Number (990) & Percentage \\
\hline $\begin{array}{l}\text { Sex } \\
\text { Male } \\
\text { Female } \\
\end{array}$ & $\begin{array}{l}618 \\
372\end{array}$ & $\begin{array}{l}62.4 \\
37.6\end{array}$ \\
\hline $\begin{array}{c}\text { Weight (gm) } \\
<1000 \\
1000- \\
\geq 1500\end{array}$ & $\begin{array}{l}103 \\
260 \\
627\end{array}$ & $\begin{array}{l}10.4 \\
26.3 \\
63.3\end{array}$ \\
\hline $\begin{array}{l}\text { Preterm (premature) } \\
\quad<37 \text { weeks } \\
\quad \geq 37 \text { weeks }\end{array}$ & $\begin{array}{l}268 \\
222\end{array}$ & $\begin{array}{l}77.6 \\
22.4\end{array}$ \\
\hline $\begin{array}{l}\text { Number of births } \\
\text { Single } \\
\text { Multiple }\end{array}$ & $\begin{array}{l}703 \\
287 \\
\end{array}$ & $\begin{array}{l}71 \\
29 \\
\end{array}$ \\
\hline $\begin{array}{l}\text { Type of Delivery } \\
\text { Vaginal } \\
\text { Caesarean }\end{array}$ & $\begin{array}{l}458 \\
532\end{array}$ & $\begin{array}{l}46.3 \\
53.7\end{array}$ \\
\hline $\begin{array}{l}\text { Premature rupture of membranes (>24hs before delivery) } \\
\text { Yes } \\
\text { No }\end{array}$ & $\begin{array}{l}188 \\
802 \\
\end{array}$ & $\begin{array}{l}19 \\
81 \\
\end{array}$ \\
\hline $\begin{array}{l}\text { Meconium stained amniotic fluid. } \\
\text { Yes } \\
\text { No }\end{array}$ & $\begin{array}{c}29 \\
961 \\
\end{array}$ & $\begin{array}{c}2.9 \\
97.1 \\
\end{array}$ \\
\hline $\begin{array}{l}\text { Enteral feeding } \\
\text { Yes } \\
\text { No }\end{array}$ & $\begin{array}{l}546 \\
444 \\
\end{array}$ & $\begin{array}{l}55.2 \\
44.8 \\
\end{array}$ \\
\hline $\begin{array}{l}\text { Ryle } \\
\text { Yes } \\
\text { No }\end{array}$ & $\begin{array}{l}403 \\
143 \\
\end{array}$ & $\begin{array}{c}73.8^{*} \\
26.2\end{array}$ \\
\hline $\begin{array}{l}\text { Parentral feeding } \\
\text { Yes } \\
\text { No }\end{array}$ & $\begin{array}{c}949 \\
41\end{array}$ & $\begin{array}{c}95.9 \\
4.1\end{array}$ \\
\hline $\begin{array}{l}\text { Mechanical ventilation } \\
\text { Yes } \\
\text { No }\end{array}$ & $\begin{array}{l}521 \\
469 \\
\end{array}$ & $\begin{array}{l}52.6 \\
47.4\end{array}$ \\
\hline $\begin{array}{l}\text { Intravascular cannula (peripheral vascular catheter) } \\
\text { Yes } \\
\text { No }\end{array}$ & $\begin{array}{l}624 \\
366\end{array}$ & $\begin{array}{l}63.0 \\
37.0\end{array}$ \\
\hline $\begin{array}{l}\text { Umbilical catheter } \\
\text { Yes } \\
\text { No }\end{array}$ & $\begin{array}{l}563 \\
427\end{array}$ & $\begin{array}{l}56.9 \\
43.1\end{array}$ \\
\hline $\begin{array}{l}\text { Transport out side the NICU } \\
\text { Yes } \\
\text { No }\end{array}$ & $\begin{array}{l}247 \\
743\end{array}$ & $\begin{array}{l}24.9 \\
75.1 \\
\end{array}$ \\
\hline $\begin{array}{l}\text { Out come } \\
\text { Discharged } \\
\text { Died }\end{array}$ & $\begin{array}{l}408 \\
582\end{array}$ & $\begin{array}{l}41.2 \\
58.8\end{array}$ \\
\hline
\end{tabular}

${ }^{*}$ total $=546$ 
Table (2): Incidence of nosocomial infection

\begin{tabular}{|l|c|}
\hline Incidence of nosocomial infection & \\
\hline Total number of neonates included & 990 \\
Total patient days & 6473 \\
Neonates infected (Nosocomial infection) & 158 \\
Infected patients/100 neonates & 16 \\
Infected patients/1000 patient days & 24.41 \\
\hline
\end{tabular}

Table (3): characteristics of study neonates with or without nosocomial infection in NICU in pediatric AUH (2007-2008)

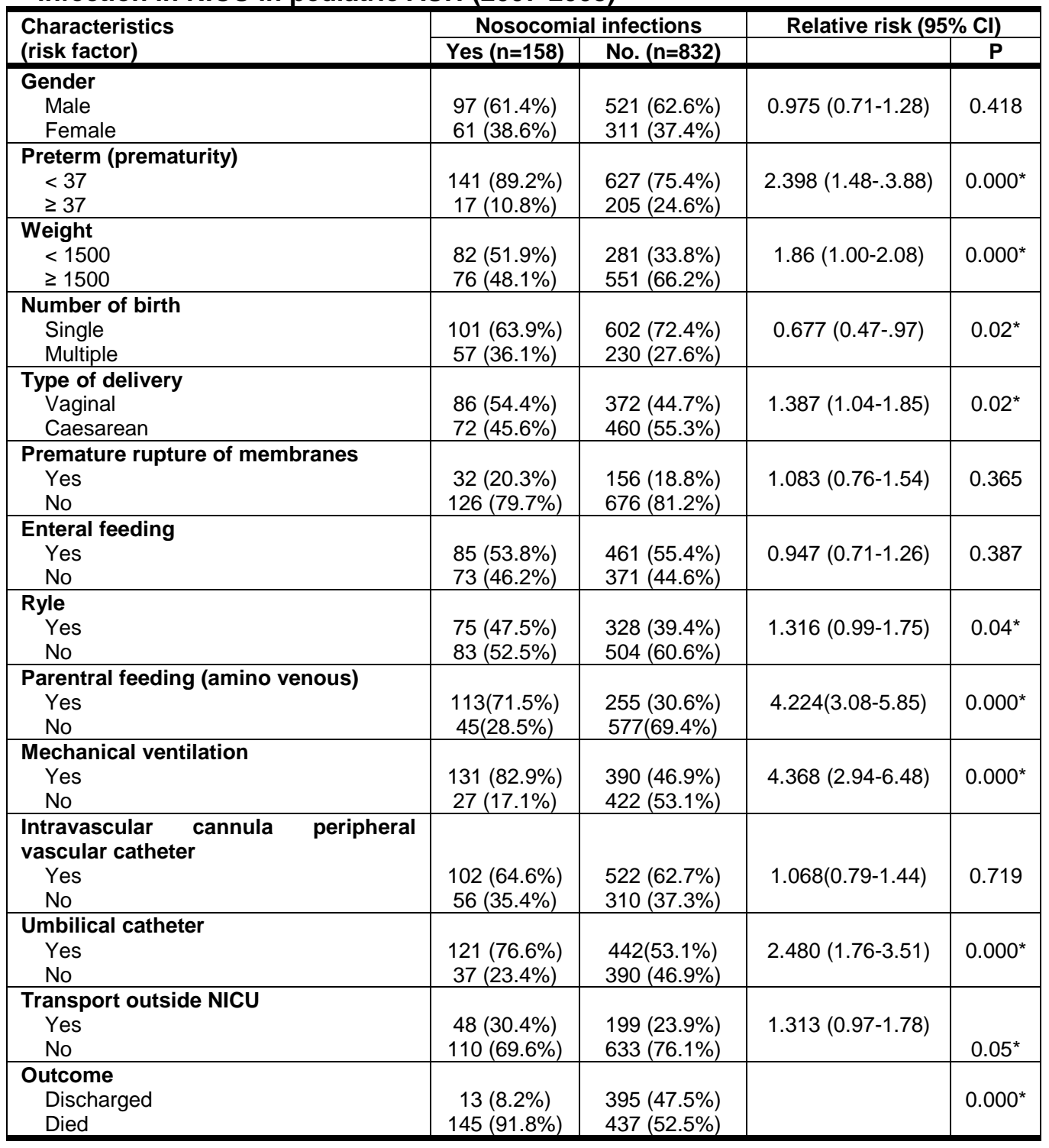


Table (4): Incidence of nosocomial infection by birth weight, gender \&both

\begin{tabular}{|c|c|c|c|}
\hline Characteristics & (N) & Infections (N) & Incidence \\
\hline $\begin{array}{c}\text { Birth weight } \\
<1000 \\
1000- \\
\geq 1500\end{array}$ & $\begin{array}{l}103 \\
260 \\
627\end{array}$ & $\begin{array}{l}11 \\
71 \\
76\end{array}$ & $\begin{array}{l}10.7 \% \\
27.3 \% \\
12.1 \%\end{array}$ \\
\hline $\begin{array}{c}\text { Gender } \\
\text { Male } \\
\text { Female }\end{array}$ & $\begin{array}{l}618 \\
372\end{array}$ & $\begin{array}{l}97 \\
61\end{array}$ & $\begin{array}{l}15.7 \% \\
16.4 \%\end{array}$ \\
\hline $\begin{array}{l}\text { Male } \\
\text { Less than } 1000 \\
1000- \\
\geq 1500 \\
\text { Total }\end{array}$ & $\begin{array}{c}47 \\
151 \\
420 \\
618\end{array}$ & $\begin{array}{c}6 \\
35 \\
56 \\
97\end{array}$ & $\begin{array}{l}12.8 \% \\
23.2 \% \\
13.3 \% \\
\mathbf{1 5 . 7} \%\end{array}$ \\
\hline $\begin{array}{l}\text { Female } \\
\text { Less than } 1000 \\
1000- \\
1500 \\
\text { Total }\end{array}$ & $\begin{array}{c}56 \\
109 \\
207 \\
372\end{array}$ & $\begin{array}{c}5 \\
36 \\
20 \\
61\end{array}$ & $\begin{array}{c}8.9 \% \\
33 \% \\
9.7 \% \\
16.4 \%\end{array}$ \\
\hline
\end{tabular}

Table (5): Incidence of nosocomial infection by preterm (prematurity) \& mechanical ventilation

\begin{tabular}{|c|c|c|c|c|}
\hline & $\begin{array}{c}\text { Mechanical } \\
\text { ventilation }\end{array}$ & Subjects & $\begin{array}{c}\text { Infections } \\
\text { (No.) }\end{array}$ & Incidence \\
\hline <37 ws & + & 449 & 117 & $26.1 \%$ \\
& - & 319 & 24 & $7.5 \%$ \\
\hline$\geq 37$ ws & + & 72 & 14 & $19.4 \%$ \\
& - & 150 & 3 & $2.0 \%$ \\
\hline Total & & $\mathbf{9 9 0}$ & $\mathbf{1 5 8}$ & $\mathbf{1 6 \%}$ \\
\hline
\end{tabular}

\section{DISCUSSION}

Our study shows that one hundred and incidence density was 24.45 neonates per fifty eight (158) neonates developed 1000 patient days and the case fatality rate nosocomial infections within 72 hs after was $91.8 \%$.

admission. The cumulative incidence rate The incidence rate and incidence was 16 per 100 admitted neonates, density rate of $\mathrm{NI}$ observed in Colombia 
were 8.4 and $6.2 \%$, respectively $\left({ }^{18)}\right.$. The rate of $\mathrm{NI}$ was 74.3 infections per 100 admissions and 2.7 infections per 100 patient-days. ${ }^{(19)}$.

The incidence rate and the incidence density rate were $50.7 \%$ and 62 infections per 1000 patient-days ${ }^{(20)}$. The incidence is high and may be due to the population at risk that stayed more than $24 \mathrm{hrs}$. The incidence of infected newborns was 14.4 per 100 newborns and $0.9 / 100$ days of stay $^{(5)}$.

Cumulative incidence rate for NIs was 30.3 neonates out of 100 admissions. The incidence density average was 10.2 neonates per 1000 patient days. The subjects were 489 neonates who were admitted to the NICU, survived longer than $72 \operatorname{hour}^{(21)}$.

The overall $\mathrm{NI}$ incidence rate observed $(34 \%)^{(22)}$. is approximately the mean of the recently reported Brazilian incidence rates (18.9\%(23), 50.7\% ${ }^{(24)}$, and $22 \%{ }^{(25)}$.

Different rates in different studies might be due to different methodologies, different durations of studies \& different infection control measures in different NICUs.

Nosocomial infections contribute to increased mortality rates. Systemic infections presenting with septic shock, hypotension, decreased tissue perfusion, profound acidosis, and end-organ failure can lead to death. Mortality rates are reported to be from $13 \%$ to $50 \%$ in infants who develop NIs, specifically those with blood stream infections and meningitis(26). The NICHD Neonatal Research Network reported the mortality rate for infants with any $\mathrm{NI}$ to be $18 \%$ as compared with an overall NICU infant mortality rate of $7 \%(3)$.

Our study shows that the risk factors most closely associated with the development of NIs were: Mechanical ventilation (RR 4.4; 95\%, Cl 2.9-6.5), Parentral feeding (amino venous) (RR 4.2; 95\%, Cl 3.08-5.85), Umbilical catheter (RR 2.5; 95\%, Cl 1.8-3.5), prematurity (RR 2.4; 95\%, Cl 1.5-3.9), weight less than $1500 \mathrm{~g}$ 
(RR 2.1; 95\%, Cl 1.5-2), vaginal delivery (RR 1.4; 95\%, Cl 1.04-1.85), use of nasogastric tube (Ryle) (RR 1.3, 95\%, Cl .991.8), Transport outside NICU (RR 1.3, $95 \%, \quad \mathrm{Cl} .97-1.8) \quad \&$ identified several modifiable risk factors associated with NIs, Mechanical ventilation, Parentral feeding (amino venous), umbilical catheter, use of naso-gastric tube (Ryle) \& transport outside NICU.

Our study shows that mechanical ventilation was the most important risk factor. In pediatric populations, the pathogenesis of VAP is not well studied but because neonates have unique characteristics predisposing them to nosocomial infections. These patients' immature immune systems place them at increased risk for infection. Skin and mucous membranes are more permeable and are less effective barriers to infection. Abnormal granulocyte migration and bacterial digestion in these patients have been demonstrated.
The risk factors were associated with NIs $(P<0.05)$ : birth weight, gestational age, mechanical ventilation, total parenteral nutrition \& umbilical catheter ${ }^{(20)}$ which concurs with our result.

The following factors were independently associated with sepsis: umbilical catheterization, both through the vein and the artery, mechanical ventilation; birth weight equal to or less than $2500 \mathrm{~g}$; nasogastric tube \& total parenteral nutrition $^{(5)}$.

The factors associated with Nls were birth weight less than $1500 \mathrm{~g}$, and gestational age less than 32 weeks $^{(21)}$.

The onset of a $\mathrm{HAl}$ was strongly associated with a low gestational age and the presence of an intravascular catheter. HAls frequently complicate hospitalization in NICUs and are associated with increased mortality(27).

The risk factors most closely associated with the development of $\mathrm{NI}$ were birth weight less than $1000 \mathrm{~g}$ (RR 1.8; 
95\% Cl 1.0-2.1), umbilical arterial powdered milk. In Nurses not using sterile catheterization (RR 5.7; 95\% $\mathrm{Cl} 1.1-28.5)$, gloves and facemasks during the and parenteral nutrition $(\mathrm{RR} 2.4 ; 95 \% \mathrm{Cl}$ preparation of formulas; the potential for $1.2-4.6)^{(19)}$. contamination secondary to human error

Birth weight $<1500 \mathrm{~g}$ and exposure to parenteral nutrition, percutaneous catheter, central venous catheter and mechanical ventilation are independent risk factors for NICU-acquired infections(22).

Use of central catheters is considered a major risk factor for $\mathrm{NI}^{(2,3,18)}$.

Our observation that naso-gastric tube feedings are a risk factor for NIs concurs with $^{(18)}$. Use of naso-gastric tubes for enteral nutrition may produce damage to the gastric mucosa directly, disrupting a natural barrier against infection. It is also possible that the apparent risk of feeding through a naso-gastric tube results from contamination of infant formulas with pathogens during their manual preparation. Owing to the higher cost of ready-toadminister infant formulas, as in our NICU prepared formulas manually using still exist.

We conclude that variation in clinical practices, either because of the requirements of the patient population or because of choices made by care providers, is the major contributor to the variation in risk between institutions.

Our study shows that incidence of nosocomial infections was high in the weight group 1000-less than 15009 $(27.3 \%)$ \& was $16.4 \%$ in females.

The incidence of infections by both gender \& birth weight was highest in both males \& females in weight group 1000-less than $1500 \mathrm{~g}(23.2 \%$ \& 33\%), respectively. Numerous studies have indicated that the risk of nosocomial infection increases with decreases in birth weight, and that birth weight was the most important risk factor $(2,10),(28),(29)$ and this concurs with our 
study. However, the incidence of factors.

nosocomial infection is very different among these studies. For example, the incidence of infections in the birth weights groups. In the boys, the incidence of infections was $32.7 \%$ in the birth weight group of less than $1,000 \mathrm{~g}, 11.1 \%$ in the birth weight group of $1,000-1,499 \mathrm{~g}$, and $4.2 \%$ in the birth weight group of more than $1,500 \mathrm{~g}$. In the girls, it was $15.9 \%$ in the birth weight group of less than $1,000 \mathrm{~g}$, $4.9 \%$ in the birth weight group of 1,000 $1,499 \mathrm{~g}$, and $3.1 \%$ in the birth weight group of more than $1,500 \mathrm{~g}$. In both genders combined,it was $25.2 \%$ in the birth weight group of less than $1,000 \mathrm{~g}, 8.4 \%$ in the birth weight group of 1,000-1,499 $\mathrm{g}$, and $3.7 \%$ in the birth weight group of more than $1,500 \mathrm{~g}^{(29)}$.

Our study shows that the incidence of Nls was the highest in the preterm with $(+)$ mechanical ventilation because preterm \& mechanical ventilation were important risk
As regard incidence of NIs by birth weight \& mechanical ventilation, no difference in incidence between $<1500 \mathrm{~g}$ (+) mechanical ventilation \& those $\geq 1500 \mathrm{~g}$ (+) mechanical ventilation $(25.4 \%$ \& $24.9 \%$, respectively.

\section{CONCLUSION}

In summary, this study has identified important modifiable risk factors for NIs. .Interventions aimed at reducing the effects of these risk factors may have the potential to decrease associated mortality, and costs of neonatal care.

Efforts to control the incidence of infection should be aimed at preventable factors, in many cases associated with external or invasive medical devices, principally through restricted use and early withdrawal, the use of adequate antiseptic techniques during insertion, manipulation, and maintenance, limiting parenteral nutrition, early feeding \& decrease use of 
ryle, and minimize transport outside unit.

Adopting a structured strategy that changes unit practices to address those risks, and evaluating the impact of the newly adopted strategies by tracking infection and organisms, the incidence of NIs in the neonatal population can be reduced.

The whole team in the NICU must follow infection control measures, our results strongly suggest the need to improve losing sight of the fact that the single most important and simplest of these measures is frequent hand washing.

\section{REFERENCES}

1- Couto RC, Tania MG, Cristina de Paula T, Enio RP. Risk Factors for Nosocomial Infection in a Neonatal Intensive Care Unit, Infection Control \& Hospital Epidemiology. (2008);27:571-5.

2- Sohn AH, Garrett DO, SinkowitzCochran RL, Grohskopf LA, Levine GL, Stover $\mathrm{BH}$, et al. Pediatric Prevention Network: Prevalence of nosocomial infections in neonatal intensive care unit patients: Results from the st national point-prevalence survey. J Pediatr. (2001);139: 821-7.
3- Stoll BJ, Hansen N, Fanaroff AA, Wright L L, Carlo WA, Ehrenkranz RA. et al. Late-onset sepsis in very low birth weight neonates: the experience of the NICHD. Neonatal Research Network.Pediatrics. 2002;110:285-91.

4- Mahieu LM, Buitenweg N, Beutels, De Dooy JJ. Additional hospital stay and charges due to hospital-acquired infections in a neonatal intensive care unit. J Hosp Infect. 2001;47:223-9.

5- Moro ML, De Toni A, Stolfi I, Carrieri MP, Braga M, Zunin C. Risk factors for nosocomial sepsis in newborn intensive and intermediate care units. Eur $\mathrm{J}$ Pediatr. 1996; 155:315-22.

6- Bilal NE, Gedebou M, Al-Ghamdi. Endemic nosocomial infections and Misuse of antibiotics in a maternity hospital in Saudi Arabia. APMIS. 2002; 110:140-7.

7- Huang YC, Lee CY, Su LH, Chang LY and Lin TY. Methicillin resistant Staphylococcus aureus bacteremia in neonatal intensive care units: genotyping analysis and case-control study. Acta Paediatr Taiwan. (2005);46: 156-60.

8- Clark R, Powers R, White R, Bloom B, Sanchez $P$, Benjamin DK. Prevention and treatment of nosocomial sepsis in the NICU. J Perinatl. (2004) 24: 446-53.

9- Clark R, Powers R, White R, Bloom B, Sanchez P, Benjamin DK .Nosocomial infection in the NICU: a medical complication or unavoidable problem. J Perinatol. (2004);24: 382-8.

10- Ferguson JK, Gill A. Risk-stratied nosocomial infection surveillance in a neonatal intensive care unit: report on 24 months of surveillance. J Pediatr Child Health. (1996);32: 525-31.

11- Garner JS, Jarvis WR, Emori TG, Horan TC, Hughes JM. CDC definitions 
for nosocomial infections, 1988. Am J Infect Control.1988; $16: 128-40$

12- Goldmann DA, Huskins WC: Control of nosocomial antimicrobial- resistant bacteria: a strategic priority for hospitals worldwide. Clin Infect Dis. (1997);24: S139-54.

13- Boyce JM, Pittet D. Healthcare Infection Control Practices Advisory Committee. Society for Healthcare Epidemiology of America. Association for Professionals in Infection Control. Infectious Diseases Society of America. Hand Hygiene Task Force: Guidelines for hand hygiene in health-care settings. Am J Infect Control. (2002);30: S1-46.

14- Cohen B, Saiman L, Cimiotti J, Larson E. Factors associated with hand hygiene practices in two neonatal intensive care units. Pediatr Infect Dis J. (2003);22:494-9.

15- Shiojima T, Ohki Y, Nako Y, Morikawa A, Okubo T, lyobe S. Immediate control of a methicillin resistant Staphylococcus aureus outbreak in a neonatal intensive care unit. J Infect Chemother. (2003); 9: 243-7.

16- Muto CA, Jernigan JA, Ostrowsky BE, Richet HM, Jarvis WR, Boyce JM, Farr BM. SHEA: guideline for preventing nosocomial transmission of multidrugresistant strains of Staphylococcus aureus and enterococcus. Infect Control Hosp Epidemiol. (2003); 24: 362-86.

17- Horan TC, Gaynes RP. Surveillance definitions- hospital (CDC-NNIS). Surveillance of nosocomial infections. In:Hospital Epidemiology and Infection Control, 3rd ed., Mayhall CG, editor. Philadelphia: Lippincott,Williams \& Wilkins; 2004:1659-1702.ven misleading (27).
18- Efird M, Rojas MA, Lozano JM, Bose CL, Rojas MX, Rondón MA, et al. Epidemiology of nosocomial infection in selected neonatal intensive care units in Colombia S-A Colombian Neonatal Research Network. J Perinatol. 2005;25:531-6.

19- Mireya UA, Mart PO, Xavier KV, Cristina LO, Miguel MM, Magda CM. Nosocomial infections in paediatric and neonatal intensive care units, Journal of Infection. 2007;54:212-20

20- Edison N ,BRITO A SJ, Matsuo T. Nosocomial infections in a neonatal intensive care unit: Incidence and risk factors, American Journal of Infection Control. 2008: 30:26-31.

21- Jeong I S, Jeong J S, Choi EO. Nosocomial infection in a newborn intensive care unit (NICU), South Korea. BioMed Central Infectious Diseases. 2006: 6:103, PubMed .

22- Távora AC, Antonieta B. Castroll, Maria Afonsina M. Militãoll; José Eduilton et al.,: Risk factors for nosocomial infection in a Brazilian neonatal intensive care unit,Brazilian Journal of Infectious Diseases. 2008;12(1).

23- Kawagoe JY, Segre CAM, Pereira CR, et al. Risk factors for nosocomial infections in critically ill newborns: A 5year prospective cohort study. Am J Infect Control. 2001;29:109-14.

24- Nagata E, Brito ASJ, Matsuo T. Nosocomial infections in a neonatal intensive care unit: Incidence and risk factors. Am J Infect Control. 2002; 30:26-31.

25- Pessoa-Silva CL, Richtmann R, Calil $R$, Rangel RM, Maria L M, Costa RN, et al. Healthcare-associated infections among neonates in Brazil. Infect Control and Hosp Epidemiol. 2004;25:772-7. 
26- Gomella TL, Cunningham MD, Eyal FG, Zenk KE. Infectious diseases. In: Gomella TL, Cunningham MD, Eyal FG, Zenk KE, eds. Neonatology: Management, Procedures, On-Call Problems, Diseases and Drugs. 4th ed. New York, NY: Lange Medical Books/McGraw-Hill; 2004:434-468.

27- Maccallini A, Diliso G, Diciommot V, Ronchetti MP, Orzalesi M. Risk factors for nosocomial infections in a neonatal intensive-care unit, The Journal of Hospital Infection. 2008.53:25-30. CAT. INIST.
28- Auriti C, Macallini A, Di Liso G, Di Ciommo V, Ronchetti MP, Orzalesi M: Risk factors for nosocomial infections in a neonatal intensive-care unit. J Hosp Infect. (2003);53: 25-30.

29- Babazono A, Hiroyuki K, Shigeru N, Tomohiko $\mathrm{N}$, et al. Risk Factors for Nosocomial Infection in the Neonatal Intensive Care Unit by the Japanese Nosocomial Infection Surveillance (JANIS), Acta Medica Okayama. (2008);62(4): . 